\title{
Elemental Composition of Soils Mixed with the Grape Molasses
}

\author{
Aslı Kurnaz*, Şeref Turhan, Muazzez Gezelge, Aybaba Hançerlioğulları, Mehmet Atıf Çetiner
}

Department of Physics, Faculty of Arts and Sciences, Kastamonu University,37150 Kastamonu, Turkey

\section{A R T I C LE IN F O}

Article history:

Received 07 June 2016

Accepted 29 June 2016

Available online, ISSN: 2148-127X

Keywords:

Molasses Soil

Chemical Composition

Oxides

EDXRF

Zile

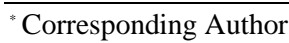

E-mail: akurnaz@kastamonu.edu.tr

\begin{abstract}
A B S T R A C T
Molasses, which is a traditional food substance obtained by boiling the fruit with local procedures and is abundantly eaten by Turkish people, are commonly produced from grapes. Zile, which is county of Tokat city placed in Central Black Sea region, is famous with molasses in Turkey. A special soil called as molasses soil containing $\mathrm{CaO}$ is added into to molasses in order to resolve acidification during production process. The purpose of this study is to determine the element concentration levels in grabe molasses soil samples collected from Zile by using energy dispersive X-ray fluorescence spectrometry (EDXRF). For this purpose, thirty-eight elements and eleven oxides were detected in molasses soil samples. The average concentrations of six major oxides $\left(\mathrm{MgO}, \mathrm{Al}_{2} \mathrm{O}_{3}\right.$, $\mathrm{SiO}_{2}, \mathrm{~K}_{2} \mathrm{O}, \mathrm{CaO}$ and $\mathrm{Fe}_{2} \mathrm{O}_{3}$ ) were found as $1.58 \%, 7.96 \%, 17.01 \%, 1.01 \%, 30.52 \%$ and $8.72 \%$, respectively. Also, the average concentrations of three minor $\left(\mathrm{Na}_{2} \mathrm{O}, \mathrm{P}_{2} \mathrm{O}_{5}, \mathrm{TiO}_{2}\right)$ and two trace $\left(\mathrm{SO}_{3}, \mathrm{MnO}\right)$ oxides were found as $0.96 \%, 0.12 \%, 0.95 \%$ and $0.04 \%, 0.1 \%$, respectively.
\end{abstract}

Türk Tarım - Gıda Bilim ve Teknoloji Dergisi, 4(9): 748-751, 2016

\section{Pekmez Topraklarının Elementel İçeriği}

\author{
Geliş 07 Haziran 2016 \\ Kabul 29 Haziran 2016

\section{Anahtar Kelimeler:} \\ Pekmez Toprağ 1 \\ Kimyasal Bileşim \\ Oksitler \\ EDXRF \\ Zile
}

M A K A L E B İ L G İ S İ

Çevrimiçi baskı, ISSN: 2148-127X

${ }^{*}$ Sorumlu Yazar:

E-mail: akurnaz@kastamonu.edu.tr

\section{Ö Z E T}

Geleneksel bir gıda maddesi olan pekmez, meyvelerin kaynatılması ile elde edilir ve Türk insanı tarafından bolca tüketilen pekmez çoğunlukla üzümden üretilmektedir. Zile/Tokat, Türkiye'de pekmezi ile meşhur bir bölgedir. Asitlenmeyi önlemek amaciyla üretimi sırasında pekmezin içine $\mathrm{CaCO}$ içerikli özel bir toprak katılmaktadır. Bu çalışmanın amacı, enerji dağılımlı X-ışını floresans spektrometresi (EDXRF) kullanarak, pekmez topraklarındaki element konsantrasyonlarının dağılımını belirlemektir. Bu amaçla toprak örneklerinde 38 tane element ve 11 oksit analiz edilmiştir. 6 major oksitin $\left(\mathrm{MgO}, \mathrm{Al}_{2} \mathrm{O}_{3}\right.$, $\mathrm{SiO}_{2}, \mathrm{~K}_{2} \mathrm{O}, \mathrm{CaO}$ ve $\mathrm{Fe}_{2} \mathrm{O}_{3}$ ) ortalama konsantrasyonları sirasiyla \%1,58, \% 7,96, \%17,01, $\% 1,01, \% 30,52$ ve $\% 8,72$ olarak bulunmuştur. Ayrica 3 minor $\left(\mathrm{Na}_{2} \mathrm{O}, \mathrm{P}_{2} \mathrm{O}_{5}, \mathrm{TiO}_{2}\right)$ ve 2 trace $\left(\mathrm{SO}_{3}, \mathrm{MnO}\right)$ oksitin ortalama konsantrasyonları sirasıyla $\% 0,96, \% 0,12, \% 0,95$ ve $\% 0,04, \% 0,1$ olarak bulunmuştur.

\section{Introduction}

Soil can be defined as a dynamic and complex system and plays both an important role in protecting the groundwater acting and contribute to the maintenance of all forms of life that occur in the terrestrial surface (De Sousa et al., 2008). Soil pollution by heavy metals is a significant and increasingly common environmental problem all over the World ( $\mathrm{Hu}$ et al., 2013; Alloway, 1995). Heavy metals can occur naturally in the soil, but rarely at toxic levels. The geologic and anthropogenic activities increase the concentration (Chibuike and Obiora, 2014). Mining, manufacturing, burning of fossil fuels, use of fertilizers and pesticides in agriculture, batteries and other metal products in industries and

municipal waste disposal can cause in heavy metal contamination of urban and agricultural soils (USDA, 2000).

Heavy metal contamination refers to the excessive deposition of toxic heavy metals in the soil caused by human activities. Heavy metal contamination is colourless and odourless. It is difficult to be noticed and does not clearly damage the environment in a short period. When environmental conditions have changed or the heavy metal concentration exceeds the environmental tolerance, heavy metal accumulation in the soil can degrade soil quality; reduce crop yield and the quality of agricultural products. Also, once the soil suffers from heavy metal 
contamination, it is difficult to be remediated. This situation cause serious ecological damage and thus negatively impacts the health of human, animals due to their non-biodegradability and tendency to accumulate in plants, animal and human tissues ( $\mathrm{Su}$ et al., 2014; Nagajyoti et al., 2010; De Souza et al., 2013).

Heavy metals are elements that exhibit metallic properties such as ductility, malleability, conductivity and cation stability. They are characterized by relatively high density and high relative atomic weight with an atomic number greater than 20 (Alloway, 1990; Chibuike and Obiora, 2014). The concentrations of some heavy metals are beneficial and essentially required for normal body growth and functions of living organisms such as metal nutritional requirements $(\mathrm{Cu}, \mathrm{Fe}, \mathrm{Mn}, \mathrm{Zn}, \mathrm{Co}, \mathrm{Mo}, \mathrm{Ni}$ and $\mathrm{V})$. On the other hand, the heavy metals in the soil include some significant metals of biological toxicity, such as mercury $(\mathrm{Hg})$, cadmium $(\mathrm{Cd})$, lead $(\mathrm{Pb})$, chromium $(\mathrm{Cr})$ and arsenic (As), etc.

In recent years, with the development of the global economy, both type and content of heavy metals in the soil caused by human activities have gradually increased, resulting in the deterioration of the environment ( $\mathrm{Su}$ et al., 2014; Sayyed and Sayadi, 2011; Raju et al., 2013; Prajapati and Meravi, 2014; Zojaji et al., 2014). Thus, it is important to identify the quantifying of heavy metal concentrations, to determine the spatial variability in the soils and to monitor possible changes. The aim of this research is to ascertain the heavy metal concentrations of soils mixed with the grape molasses collected from Zile/Tokat region which is famous with grape molasses which is an abundantly consumed foodstuff in Turkey (Zile molasses). Molasses soil is added into to Zile grape molasses during production to resolve acidification of its (Kurnaz et al., 2016). Up to now, no survey has been reported on the heavy metal concentrations of the Zile molasses soil. In addition, this information will contribute to the literature of the heavy metal pollution measurements in soil.

\section{Material and Methods}

\section{Sample Collection and Preparation}

Zile is a county of Tokat Province in the Black Sea region of Turkey and is $67 \mathrm{~km}$ away from Tokat city centre. The study area lies between $40^{\circ} 19^{\prime} \mathrm{N}$ and $35^{\circ} 45^{\prime} \mathrm{E}$ (peak elevation: $2428 \mathrm{~m}$, elevation: $740 \mathrm{~m}$ average height above sea level for the entire province) and covers an area of $1542 \mathrm{~km}^{2}$. The study area has a geology that shows various lithological units beginning from Palaeozoic formations consisted of partly marbled limestones extending to Quaternary Era (Anonymous, 2014; Kurnaz et al., 2016). According to the 2014 census, population of Zile region is 56727 .

The five different type molasses soil samples were collected from uncultivated locations of the study area. After cleaning the ground from stones, pebbles and vegetation, about $1 \mathrm{~kg}$ of material from the first $15 \mathrm{~cm}$ of top soil samples was placed in polythene bags. The samples were first pulverized and air dried at room temperature in open air. The samples were sieved to about 100 meshes. About $50 \mathrm{~g}$ of each homogenized sample was packed in polyethylene containers.

\section{Heavy Metal Concentrations in Soil}

The elemental analysis survey was conducted using energy dispersive X-ray fluorescence (Spectro Xepos, Ametek). This device is a very versatile EDXRF spectrometer. It optimizes excitation using polarization and secondary targets. It has an auto sampler for up to 12 items and software modules. It uses a 50 watt endwindow X-ray tube to excite the samples. The target changer, with up to 8 polarization and secondary targets, offers many different excitation conditions ensuring optimum determination of all elements from ${ }^{11} \mathrm{Na}$ to ${ }^{92} \mathrm{U}$. The measurements are conducted in Helium gas atmosphere. A spectral resolution of less than $155 \mathrm{eV}$ at $\mathrm{Mn} K_{\gamma}$ is achieved. The sample chamber is equipped with a sample spinner for $40 \mathrm{~mm}$ sample cups (Anonymous, 2015).

\section{Results and Discussion}

Five type soil samples mixed into molasses collected from Zile county of Tokat province in Turkey were analysed using EDXRF spectrometer for determining chemical compositions and elemental distribution of the samples.

The concentrations of the oxides and elements in the samples were ascertained and compared with their mean abundance in the earth's crust (Yaroshevsky, 2006) (Table 1,2). The major, minor and trace element contents, expressed as weight percentage of oxides, for the molasses soils are reported in Table 1. As can be seen from Table 1, among the major oxides, the mean concentrations of $\mathrm{CaO}$ and $\mathrm{Fe}_{2} \mathrm{O}_{3}$ are higher than the mean abundance of earth's crust. $\mathrm{TiO}_{2}$ is single minor oxide and $\mathrm{SO}_{3}$ is single trace oxide which have larger the mean concentration than the mean abundance of earth's crust while the mean concentrations of the other oxides are lower than or equal the mean abundance of earth's crust.

Table 1 Distribution of the major, minor and trace oxides concentrations and their earth's crust abundance (\%)

\begin{tabular}{l|ccccccccccc}
\hline Molasses soils & $\mathrm{Na}_{2} \mathrm{O}$ & $\mathrm{MgO}$ & $\mathrm{Al}_{2} \mathrm{O}_{3}$ & $\mathrm{SiO}_{2}$ & $\mathrm{P}_{2} \mathrm{O}_{5}$ & $\mathrm{~K}_{2} \mathrm{O}$ & $\mathrm{CaO}$ & $\mathrm{TiO}_{2}$ & $\mathrm{Fe}_{2} \mathrm{O}_{3}$ & $\mathrm{SO}_{3}$ & $\mathrm{MnO}$ \\
\hline First kind & 0.766 & 0.571 & 1.688 & 4.991 & 0.111 & 1.513 & 48.5 & 0.142 & 0.839 & 0.067 & 0.085 \\
Second kind & 0.861 & 1.672 & 13.03 & 24.54 & 0.144 & 2.346 & 22.97 & 1.411 & 13.24 & 0.034 & 0.106 \\
Third kind & 1.379 & 2.777 & 11.18 & 25.35 & 0.104 & 1.123 & 19.77 & 1.336 & 12.09 & 0.019 & 0.119 \\
Fourth kind & 0.762 & 1.26 & 6.755 & 14.21 & 0.114 & 0.862 & 30.78 & 0.894 & 8.676 & 0.043 & 0.096 \\
Fifth kind & 1.031 & 1.629 & 7.141 & 15.95 & 0.119 & 0.709 & 30.56 & 0.943 & 8.755 & 0.047 & 0.115 \\
Mean & 0.96 & 1.58 & 7.96 & 17.01 & 0.12 & 1.31 & 30.52 & 0.95 & 8.72 & 0.04 & 0.1 \\
Standard Deviation & 0.26 & 0.80 & 4.40 & 8.36 & 0.02 & 0.65 & 11.13 & 0.50 & 4.85 & 0.02 & 0.01 \\
MAES & 2.74 & 4.91 & 16.17 & 54.55 & 0.2 & 1.32 & 8.72 & 0.86 & 0.92 & 0.063 & 0.159 \\
\hline
\end{tabular}

MAES: Mean abundance in the earth's crust 
Table 2 Elemental analysis results of molasses soil samples and their earth's crust abundance ( $\left.\mathrm{mgkg}^{-1}\right)$

\begin{tabular}{|c|c|c|c|c|c|c|c|c|}
\hline $\begin{array}{c}\text { Elements } \\
\left(\mathrm{mgkg}^{-1}\right)\end{array}$ & $\begin{array}{l}\text { First } \\
\text { kind }\end{array}$ & $\begin{array}{l}\text { Second } \\
\text { kind }\end{array}$ & $\begin{array}{l}\text { Third } \\
\text { kind }\end{array}$ & $\begin{array}{l}\text { Fourth } \\
\text { kind }\end{array}$ & $\begin{array}{l}\text { Fifth } \\
\text { kind }\end{array}$ & Mean & $\begin{array}{c}\text { Standard } \\
\text { Deviation }\end{array}$ & $\begin{array}{l}\text { Mean abundance in the } \\
\text { earth's }\end{array}$ \\
\hline $\mathrm{Na}$ & 5680 & 6380 & 10230 & 5660 & 7650 & 7120 & 1715 & 25000 \\
\hline $\mathrm{Mg}$ & 3440 & 10080 & 16750 & 7598 & 9825 & 9539 & 4321 & 18700 \\
\hline $\mathrm{Al}$ & 8932 & 68950 & 59170 & 35750 & 37800 & 42120 & 20839 & 80500 \\
\hline $\mathrm{Si}$ & 23330 & 114700 & 118500 & 66400 & 74540 & 79494 & 34961 & 295000 \\
\hline $\mathrm{P}$ & 484.5 & 629.2 & 454.6 & 497.7 & 521.5 & 517.5 & 59.9 & 930 \\
\hline $\mathrm{S}$ & 270.5 & 134.9 & 76.8 & 171.7 & 187.5 & 168.3 & 63.7 & 470 \\
\hline $\mathrm{K}$ & 12560 & 19470 & 9321 & 7155 & 5890 & 10879 & 4854 & 25000 \\
\hline $\mathrm{Ca}$ & 346600 & 164200 & 141300 & 220000 & 218400 & 218100 & 71161 & 29600 \\
\hline $\mathrm{Ti}$ & 852 & 8457 & 8008 & 5361 & 5655 & 5667 & 2703 & 4500 \\
\hline $\mathrm{V}$ & 59.2 & 274.6 & 299.9 & 202.9 & 216.5 & 210.6 & 83.8 & 90 \\
\hline $\mathrm{Cr}$ & 21.9 & 497 & 372.1 & 265.7 & 362.2 & 303.8 & 158.9 & 83 \\
\hline Mn & 660.5 & 819.2 & 924.9 & 746.6 & 893.5 & 808.9 & 96.6 & 1000 \\
\hline $\mathrm{Fe}$ & 5864 & 92610 & 84540 & 60680 & 61230 & 60985 & 30310 & 46500 \\
\hline $\mathrm{Co}$ & 19.4 & 13.5 & 35.7 & 15.2 & 24.6 & 21.7 & 8.0 & 18 \\
\hline $\mathrm{Ni}$ & 14.9 & 150.9 & 310.3 & 145.1 & 195 & 163.2 & 95.0 & 58 \\
\hline $\mathrm{Cu}$ & 8 & 27.3 & 45.5 & 26.3 & 31.6 & 27.7 & 12.0 & 47 \\
\hline $\mathrm{Zn}$ & 12.8 & 59.7 & 101.2 & 52.7 & 66.6 & 58.6 & 28.3 & 83 \\
\hline $\mathrm{Ga}$ & 4.1 & 17.6 & 20.4 & 13.6 & 15.5 & 14.2 & 5.6 & 19 \\
\hline As & 3.6 & 91.3 & 86 & 58 & 58.4 & 59.5 & 31.1 & 1.7 \\
\hline $\mathrm{Br}$ & 10.2 & 2.1 & 2.5 & 4 & 4.2 & 4.6 & 2.9 & 2.1 \\
\hline $\mathrm{Rb}$ & 3.8 & 63.3 & 41 & 35.7 & 31.8 & 35.1 & 19.1 & 150 \\
\hline $\mathrm{Sr}$ & 211.2 & 74.3 & 131.7 & 132.9 & 140.5 & 138.1 & 43.6 & 340 \\
\hline $\mathrm{Y}$ & 4.6 & 17.3 & 20.8 & 15.5 & 15.3 & 14.7 & 5.4 & 29 \\
\hline $\mathrm{Zr}$ & 23.8 & 127.1 & 118.8 & 101.6 & 89.3 & 92.1 & 36.6 & 170 \\
\hline $\mathrm{Cd}$ & 2.5 & 1.5 & 0.6 & 0.9 & 1.8 & 1.5 & 0.7 & 0.13 \\
\hline $\mathrm{Sn}$ & 14.4 & 5.3 & 12.7 & 1.2 & 11.7 & 9.1 & 5.0 & 2.5 \\
\hline $\mathrm{Sb}$ & 6.8 & 13.3 & 10.2 & 3.5 & 8.4 & 8.4 & 3.3 & 0.5 \\
\hline $\mathrm{Te}$ & 19.8 & 19.3 & 19.1 & 16 & 14.6 & 17.8 & 2.1 & 0.001 \\
\hline I & 6.7 & 1.8 & 3.2 & 2.4 & 5.3 & 3.9 & 1.8 & 0.4 \\
\hline $\mathrm{Ba}$ & 24.5 & 142.5 & 89.4 & 89.2 & 64.5 & 82.0 & 38.4 & 650 \\
\hline $\mathrm{La}$ & 0 & 0 & 3.3 & 0 & 13.3 & 3.3 & 5.2 & 29 \\
\hline $\mathrm{Ce}$ & 33.1 & 15.7 & 0 & 0 & 0 & 9.8 & 13.2 & 70 \\
\hline $\mathrm{Pr}$ & 25.1 & 4.6 & 0 & 6.3 & 0 & 7.2 & 9.3 & 9 \\
\hline $\mathrm{Nd}$ & 35.8 & 17.4 & 12.1 & 9.1 & 14 & 17.7 & 9.5 & 37 \\
\hline $\mathrm{Ta}$ & 25.9 & 28.7 & 26.2 & 22.6 & 24.6 & 25.6 & 2.0 & 2.5 \\
\hline $\mathrm{Hg}$ & 2.3 & 3 & 1.1 & 2 & 1.4 & 2.0 & 0.7 & 0.083 \\
\hline $\mathrm{Pb}$ & 3.7 & 8.5 & 10.1 & 6.5 & 7.1 & 7.2 & 2.1 & 16 \\
\hline Th & 2.3 & 4.7 & 2.9 & 4.2 & 2.7 & 3.4 & 0.9 & 13 \\
\hline
\end{tabular}

The mean concentrations of $\mathrm{Ca}$ (Calcium), $\mathrm{Ti}$ (Titanium), V (Vanadium), Cr (Chromium), Fe (Iron), Co (Cobalt), Ni (Nickel), As (Arsenic), Br (Bromine), Cd (Cadmium), Sn (Tin), Sb (Antimony), Te (Tellurium), I (Iodine), Ta (Tantalum), and $\mathrm{Hg}$ (Mercury) are higher than their mean abundance of earth crust (Table 2). Among the metals analysed in this research, toxic elements $\mathrm{Cd}, \mathrm{Hg}, \mathrm{Pb}$ (Lead) and as are especially important because these metals are in the World Health Organisation's list of ten chemicals of major public health concern (WHO, 2010). The concentrations of $\mathrm{Cd}, \mathrm{Hg}, \mathrm{Pb}$ and As were determined in the ranges $0.6-2.5,1.1-3,3.7-$ 10.1 and $3.6-91.3 \mathrm{mgkg}^{-1}$ for all of the soil samples with corresponding mean values of $1.5,2,7.2$ and $59.5 \mathrm{mgkg}^{-1}$, respectively. When the Table 2 is examined, it is clearly seen that the mean concentrations of $\mathrm{As}, \mathrm{Hg}$ and $\mathrm{Cd}$ in the molasses soil samples are 35, 24.1 and 11.5 times higher while $\mathrm{Pb}$ is 2.2 times lover than the their mean abundance in the earth's crust.

The concentrations of some heavy metals (Na (Sodium), Mg (Magnesium), P (Phosphorus), S (Sulphur), $\mathrm{K}$ (Potassium), Ca (Calcium), Mn (Manganese), Fe, Co, $\mathrm{Ni}, \mathrm{Cu}$ (Copper), $\mathrm{Zn}$ (Zinc) and I) are essential for numerous enzymes involved in numerous body functions for human health (Prashanth et al., 2015). The concentrations of these heavy metals were ascertained in the ranges 5660-10230, 3440-16750, 454.6-629.2, 76.8270.5, 5890-19470, 141300- 346600, 660.5-924.9, 5864$92610,13.5-35.7,14.9-310.3,8-45.5,12.8-101.2$ and 1.8$6.7 \mathrm{mgkg}^{-1}$, respectively for all of the soil samples. The mean concentrations of these metals were found to be 7120, 9539, 517.5, 168.3, 10879, 218100, 808.9, 60985, $21.7,163.227 .758 .6$ and $3.9 \mathrm{mgkg}^{-1}$, respectively in this research (Table 2). As can be seen from the results, between the essential heavy metals for body functions, the mean concentration of $\mathrm{Ca}, \mathrm{Fe}, \mathrm{Co}, \mathrm{Ni}$ and $\mathrm{I}$ are notable higher than the their mean abundance in the earth's crust.

The concentration of $\mathrm{Th}$ (Thorium) radioactive elements detected in all soil samples varied from 2.3 to $4.7 \mathrm{mgkg}^{-1}$ and the mean value was found as $3.4 \mathrm{mgkg}^{-1}$. Also in this research, Y (Yttrium), La (Lanthanum), Ce (Cerium), Pr (Praseodymium) and $\mathrm{Nd}$ (Neodymium) which is known as rare earth elements was observed. Y and $\mathrm{Nd}$ were determined in all samples in the ranges 4.6$20.8 \mathrm{mgkg}^{-1}$ and $9.1-35.8 \mathrm{mgkg}^{-1}$ with corresponding mean values of $14.7 \mathrm{mgkg}^{-1}$ and $17.7 \mathrm{mgkg}^{-1}$, respectively. La was determined only $3^{\text {rd }}$ and $5^{\text {th }}$ type soil samples while Ce was determined $1^{\text {st }}$ and $2^{\text {nd }}$ type soil samples. The concentrations of $\mathrm{La}$ and $\mathrm{Ce}$ were ascertained as $3.3 \mathrm{mgkg}^{-1}, 13.3 \mathrm{mgkg}^{-1}$ and $33.1 \mathrm{mgkg}^{-1}$, 
$15.7 \mathrm{mgkg}^{-1}$, respectively. Pd was determined in three sample type and the mean value was found to be 7.2 $\mathrm{mgkg}^{-1}$. The highest concentration of $\mathrm{Nd}\left(35.8 \mathrm{mgkg}^{-1}\right), \mathrm{Pr}$ $\left(25.1 \mathrm{mgkg}^{-1}\right)$ and $\mathrm{Ce}\left(33.1 \mathrm{mgkg}^{-1}\right)$ was determined in first kind of the molasses soil samples (Table 2).

\section{Conclusion}

Environmental contamination with chemicals and heavy metals from different sources has become a global concern since 1990's. Anthropogenic activities such as agriculture and industrial processing are the main sources of heavy metal contamination in the environment. These contaminations under certain conditions have important reflection both the environment and human health because heavy metals may accumulate to a toxic concentration level, which can lead to ecological damages. Because of this reason, elemental analysis of the five different types of the molasses soil samples collected from Zile/Tokat region in Turkey using EDXRF technique. Because the molasses soils are directly incorporated into the foodstuff (grape molasses), it is even more important to determine of the element concentrations in the soils. $\mathrm{Na}_{2} \mathrm{O}, \mathrm{MgO}, \mathrm{Al}_{2} \mathrm{O}_{3}, \mathrm{SiO}_{2}, \mathrm{P}_{2} \mathrm{O}_{5}$, $\mathrm{K}_{2} \mathrm{O}, \mathrm{CaO}, \mathrm{TiO}_{2}, \mathrm{Fe}_{2} \mathrm{O}_{3}, \mathrm{SO}_{3}, \mathrm{MnO}$ oxides and the specific element concentrations given Table 2 were detected. The mean concentrations of $\mathrm{Ca}, \mathrm{Ti}, \mathrm{V}, \mathrm{Cr}, \mathrm{Fe}$, $\mathrm{Co}, \mathrm{Ni}, \mathrm{As}, \mathrm{Br}, \mathrm{Sn}, \mathrm{Sb}, \mathrm{Te}, \mathrm{I}$ and $\mathrm{Ta}$ are higher than their average abundance in the earth's crust. The accumulations of $\mathrm{Cd}, \mathrm{Hg}, \mathrm{Pb}$, and especially As were observed through the investigation of the molasses soil samples. These elements are not essential for body growth. It is well known theirs toxic effects. The major threat to human health of $\mathrm{Cd}$ is chronic accumulation in the kidneys leading to kidney dysfunction and $\mathrm{Pb}$ can cause serious injury to the brain, nervous system, red blood cells, and kidneys (Baldwin and Marshall, 1999; Wuana and Okieiman, 2011). $\mathrm{Hg}$ is associated with kidney damage and As is associated with skin damage, increased risk of cancer and the cause problems with circulatory system (Scragg, 2006; Wuana and Okieiman, 2011). Among the all metal analysed, it is said that As has the highest risk because the mean value was 35 times higher than the earth's crust abundance and this accumulation comes from probably both natural and anthropogenic sources. The results of the present study will be valuable database in keep track and assessment of soil pollution.

\section{References}

Alloway BJ. 1990. Heavy Metal in Soils, John Wiley \& Sons, New York, NY, USA.

Alloway BJ. 1995. Heavy metals in soils, 2nd ed. Blackie Academic and Professional, London.

Anonymous. 2014. Tokat Municipality, Geographical Structure, http://www.tokat.bel.tr/icerik.php?icerik=46\&Kategori=1003.

Anonymous. 2015. Spectro Xepos Brochure, Ametek, http://www.spectro.com/products/xrf-x-ray-fluorescencespectrometer/edxrf-spectrometer-xepos.

Baldwin DR, Marshall WJ. 1999. Heavy metal poisoning and its laboratory investigation. Annals of Clinical Biochemistry, $36,3,267-300$.
Chibuike GU, Obiora SC. 2014. Heavy Metal Polluted Soils: Effect on Plants and Bioremediation Methods. Hindawi Publishing Corporation Applied and Environmental Soil Science, Article ID 752708, http://dx.doi.org/10.1155/2014 1752708

De Souza RB, Maziviero TG, Christofoletti CA, Pinheiro TG, Fontanetti CS. 2013. Soil Contamination with Heavy Metals and Petroleum Derivates: Impact on Edaphic Fauna and Remediation Strategies. Soil Processes and Current Trends in Quality Assessment, chapter 6, http://dx.doi.org/10.5772/ 52868.

Hu Y, Liu X, Bai J, Shih K, Zeng EY, Cheng H. 2013. Assessing heavy metal pollution in the surface soils of a region that had undergone three decades of intense industrialization and urbanization. Environmental Science and Pollution Research, 20, 6150-6159.

Kurnaz A, Gezelge M, Hançerlioğulları A, Çetiner MA, Turhan Ş. 2016. Radionuclides Content in Grape Molasses Soil Samples from Central Black Sea Region of Turkey. Human and Ecological Risk Assessment: An International Journal, DOI: $10.1080 / 10807039.2016 .1185356$

Nagajyoti PC, Lee KD, Sreekanth TVM. 2010. Heavy metals, occurrence and toxicity for plants: a review. Environmental Chemistry Letters, 8(3): 199-216.

Prajapati SK, Meravi N. 2014. Heavy metal speciation of soil and Calotropis procera from thermal power plant area. Proceedings of the International Academy of Ecology and Environmental Sciences, 4(2): 68-71.

Prashanth L, Kattapagari KK, Chitturi RT, Baddam VRR, Prasad LK. 2015. A review on role of essential trace elements in health and disease. Journal of Dr. NTR University of Health Sciences, 4(2): 75-85.

Raju KV, Somashekar RK, Prakash KL. 2013. Spatio-temporal variation of heavy metals in Cauvery River basin. Proceedings of the International Academy of Ecology and Environmental Sciences, 3(1): 59-75.

Sayyed MRG, Sayadi MH. 2011. Variations in the heavy metal accumulations within the surface soils from the Chitgar industrial area of Tehran. Proceedings of the International Academy of Ecology and Environmental Sciences, 1(1): 36-46.

Scragg A. 2006. Environmental Biotechnology, Oxford University Press, Oxford, UK, 2nd edition.

Su C, Jiang L, Zhang W. 2014. A review on heavy metal contamination in the soil worldwide: Situation, impact and remediation techniques. Environmental Skeptics and Critics, 3(2): 24-38.

United States Department of Agriculture (USDA). 2000. Heavy Metal Soil Contamination. Natural Resources Conservation Service, Soil Quality-Urban Technical Note No. 3, September.

World Health Organization (WHO). 2010. Public Health and Environment, International Programme on Chemical Safety, Ten chemicals of major public health concern, GenevaSwitzerland.

Wuana RA, Okieimen FE. 2011. HeavyMetals in Contaminated Soils: A Review of Sources, Chemistry, Risks and Best Available Strategies for Remediation. International Scholarly Research Network, ISRN Ecology, Volume 2011, Article ID 402647, 20 pages, doi:10.5402/2011/402647

Yaroshevsky AA. 2006. Abundances of Chemical Elements in the Earth's Crust. Geochemistry International, 44(1): 48-55.

Zojaji F, Hassani AH, Sayadi MH. 2014. Bioaccumulation of chromium by Zea mays in wastewater-irrigated soil: An experimental study. Proceedings of the International Academy of Ecology and Environmental Sciences, 4(2): 6267. 